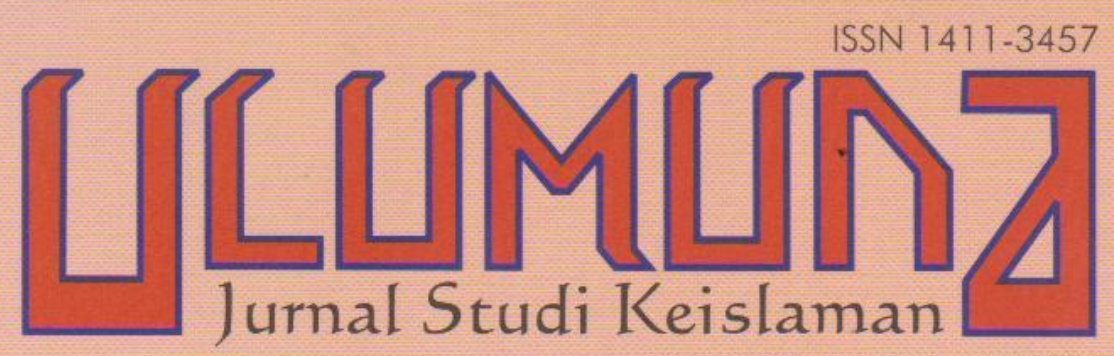

Volume XII• Nomor 1• Juni 2008

STUDI ANALITIS DIMENSI SACIFACT PENDIDIKAN ISLAM PADA MASA KEJAYAANNYA (750-1258 M) Abdul Fattah

AKTUALISASI MANUSIA VERSI AL-QUR'AN: ANTARA IDEALITAS DAN REALITAS PENDIDIKAN ISLAM Ismail Thoib

PENDIDIKAN ISLAM DAN PENCERAHAN SPIRITUALITAS: IKHTIAR MENJAWAB TANTANGAN POSMODERNISME Suparta

LESSON STUDY DALAM PEMBELAJARAN AGAMA ISLAM DI SEKOLAH UMUM Ahmad Munjin dan Khoirul Adib

STUDI PERUBAHAN KELEMBAGAAN DAN METODOLOGI PADA MADRASAH MODEL Taufik Churahman dan Musfigon POSISI PEREMPUAÑ
PERSPEKTIF ULAMA KLASIK
Baehaqi 


\section{PEDOMAN TRANSLITERASI}

\begin{tabular}{|c|c|c|c|}
\hline Arab & Latin & Arab & Latin \\
\hline 1 & $=$ & ف & $=\mathbf{f}$ \\
\hline ب & $=$ & ق & $=\mathrm{q}$ \\
\hline$\dot{H}$ & ts & ك & $=\mathbf{k}$ \\
\hline ج & $=$ & $J$ & $=1$ \\
\hline$\tau$ & $=$ & b & $=\mathrm{m}$ \\
\hline$\dot{\tau}$ & $=\quad \mathrm{kh}$ & $\dot{0}$ & $=\mathbf{n}$ \\
\hline$د$ & $=$ & و - - - 1 & $=\mathbf{w}$ \\
\hline$\dot{j}$ & $\mathrm{dz}$ & • & $=h$ \\
\hline$\jmath$ & $=$ & $\&$ & $=$, \\
\hline j & $=$ & ي & $=y$ \\
\hline س س & $=$ & & \\
\hline ش & $=$ & \multirow{2}{*}{\multicolumn{2}{|c|}{$\begin{array}{l}\text { Untuk Madd } \\
\text { dan Diftong }\end{array}$}} \\
\hline ص & sh & & \\
\hline ض & dl & i & $=$ â (a panjang) \\
\hline b & th & إين & $=\hat{\mathbf{1}}(\mathbf{i}$ panjang) \\
\hline ظ & $\mathrm{zh}$ & أوْ & $=\quad \hat{\mathbf{u}}$ (u panjang) \\
\hline$\varepsilon$ & $=$ & 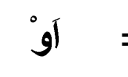 & $=a w$ \\
\hline$\dot{\varepsilon}$ & $=g h$ & آين & $=$ ay \\
\hline
\end{tabular}




\section{ISI}

TRANSLITERASI

ANTARAN

UTAMA

Abdul Fattah

Studi Analitis Dimensi Sacifact Pendidikan Islam pada Masa Kejayaannya $(750-1258 \mathrm{M}) \bullet 1-28$

Ismail Thoib

Aktualisasi Manusia Versi Al-Qur'an:

Antara Idealitas dan Realitas

Pendidikan Islam • 29-46

Suparta

Pendidikan Islam dan Pencerahan

Spiritualitas: Ikhtiar Menjawab Tantangan

Posmodernisme • 47-66

Ahmad Munjin Nasih Lesson Study dalam Pembelajaran

dan Khoirul Adib Pendidikan Agama Islam

di Sekolah Umum • 67-88

Taufik Churahman Dinamika Pendidikan Islam: Studi

dan Musfiqon

Perubahan Kelembagaan dan Metodologi

pada Madrasah Model • 89-106

LEPAS

Mutawalli Pembaruan Hukum Islam:

Menimbang Tawaran Pemikiran

'Abd al-Lâh al-Na'îm • 107-128

Baehaqi Posisi Perempuan

Perspektif Ulama Klasik • 129-142

Ahmad Sulhan Islam Kontemporer: Antara Reformasi

dan Revolusi Peradaban • 143-156

Ahmad Choirul Rofiq Menilai Kompetensi al-Mâturîdî di Bidang

Tafsir al-Qur'an • 157-182

ULAS BUKU

Yayuk Fauziyah Menyingkap Kuasa Maskulinitas di Balik

Tabir Feminitas Wanita Jawa • 183-200

INDEKS 


\title{
MENILAI KOMPETENSI AL-MÂTURÎDÎ DI BIDANG TAFSIR AL-QUR'AN
}

\author{
Ahmad Choirul Rofiq*
}

\begin{abstract}
Al-Mâturî̀î has expertise in various Islamic sciences. In the Qur'anic exegesis, he has Ta'mîlât Abl al-Sunnah or Ta'mîlât al-Qur'ân. This paper is going to explain the methodology of al-Mâturîdì's exegesis. He clearly favors to combine the naqlî and aqlî sources. Therefore, it can be identified as tafsîr bi al-izdiwâj (the exegesis which amalgamates tafsîr bi al-ma'tsûr with tafsîr bi al-ra'y). He is not an excessive commentator in using grammatical analysis to interpret the Qur'anic verses. He sometimes presents many styles of qirâ'ah (recitation of the Qur'an) without thorough elucidation. He almost never takes Isrâ'illiyyât (the Judeo-Christian traditions and tales) to interpret the Qur'anic verses. He prefers tawassuth (nonaligned and independent standpoint) when dealing with many different viewpoints among the theologians. He tends to follow the Hanafite school of thought in discussing the jurisprudential Qur'anic verses. He usually uses asbâb al-nuzûl (the causes of revelation) slackly.
\end{abstract}

Keywords: Ayat, Tafsir, Al-Qur'an, Kompetensi, Asbâb alNuzul.

PADA masa kemajuan pertama sejarah Islam, dapat disaksikan kemajuan intelektual yang mempunyai pengaruh amat signifikan terhadap perkembangan ilmu-ilmu keislaman yang tercakup di dalamnya ilmu teologi (kalam) Islam, sehingga bermunculan aliran-aliran teologi yang masing-masing selalu saling berusaha

*Penulis adalah dosen Sekolahh Tinggi Agama Islam Negeri (STAIN) Ponorogo Jawa Timur. email: rofiq8377@yahoo.co.id 
memperkokoh argumentasi mereka dengan sandaran dalil-dalil pendukung. ${ }^{1}$ Selama kurun tersebut, dijumpai sebuah langkah bijaksana dari seorang khalifah Dinasti 'Abbâssiyyah bernama alMutawakkil (w. $247 \mathrm{H} / 861 \mathrm{M}$ ) yang dengan sangat tegas membela mazhab Ahl al-Sunnah wa al-Jamâ'ah, serta kemudian berbalik menyerang mazhab Mu'tazilah dan membebaskan para ulama yang sebelumnya mengalami penyiksaan berat akibat berani mengambil sikap berseberangan terhadap mazhab Mu'tazilah yang didukung pemerintah ketika diberlakukan tindakan mibnah (inquisition atau test of faith) semenjak kekhilafahan berada di bawah kendali Khalifah al-Ma'mûn (w. $218 \mathrm{H} / 833 \mathrm{M}) .^{2}$

Menurut al-Maghribî, upaya al-Mutawakkil itu dalam perkembangan selanjutnya dapat membawa angin segar bagi tampilnya para ulama kalam mazhab Ahl al-Sunnah wa alJamâ'ah, seperti Abû al- $\underline{H} a s a n$ al-Asy'arî (w. 330 H/941 M) di Bashrah yang memproklamirkan penolakannya terhadap pemikiran Mu'tazilah dan pembelaannya terhadap pemikiran Ahl al-Sunnah wa al-Jamâ'ah, Abû Manshûr Muhammad bin Muhammad al-Mâturîdî (w. 333 H/944 M) di Samarqand khususnya, serta daerah-daerah lainnya di kawasan mâ warâ' al$n a h r^{3}$ yang berhasil menunjukkan kesalahan-kesalahan Mu'tazilah

${ }^{1}$ Keterangan lebih terperinci mengenai periodesasi sejarah Islam dan kemajuan peradabannya dapat dilihat dalam Harun Nasution, Islam Ditinjau Dari Berbagai Aspeknya, vol. 1 (Jakarta: UI Press, 1978), 56-89.

${ }^{2}$ G.E. Von Grunebaum, Classical Islam, ter. Katherine Watson (Chicago: Aldine Publishing Company, 1970), 94.

3Istilah mâ warâ' al-nahr adalah suatu istilah yang ditujukan oleh bangsa Arab kepada daerah-daerah yang terletak di sebelah utara sungai Jaihûn atau Âmou-Dariyâdi Turkistan, Rusia, yang merupakan pusat-pusat peradaban Islam: Bukhârâ, Samarqand, Khiwa dan Tachkent. Lihat Ferdinand Tawtal et.al., al-Munjid fì al-'A'lâm (Beirut: Dâr al-Masyriq, 1995), 518. Dalam bahasa lain, istilah mâ warâ' al-nahr diterjemahkan dengan 'Transoxiana (Uzbekistan). Lihat Hans Wehr, A Dictionary of Modern Written Arabic, ed. J. Milton Cowan (London: Macdonald \& Evans, 1960), 1003. 
dengan mempergunakan metode rasional, dan Abû Ja'far alThahâwî̀ (w. $321 \mathrm{H} / 933 \mathrm{M}$ ) di Mesir yang turut mempertahankan prinsip-prinsip Ahl al-Sunnah wa al-Jamâ'ah. ${ }^{4}$ Pernyataan yang senada juga dikemukakan oleh Abû al-Khayr Muhammad Ayyûb 'Alî. 5

Selain popularitasnya di bidang kalam, ternyata al-Mâturîdî juga mempunyai banyak karya ilmiah dalam bidang keilmuan lain. Secara lebih lengkap karya-karyanya berjumlah 24 judul, yaitu 2 dalam ilmu tafsir dan ilmu tajwid, 4 dalam ilmu fiqh, 12 dalam ilmu kalam, 1 dalam ilmu tasawuf, dan 5 sisanya dalam topik-topik lain yang beraneka ragam. ${ }^{6}$ Sebuah karyanya di bidang ilmu tafsir, Ta'wîlât Abl al-Sunnah. Meskipun demikian, kajian-kajian komprehensif mengenai buku tafsir itu tidak banyak dijumpai. Bahkan dalam banyak literatur mengenai ilmuilmu al-Qur'an, hampir tidak pernah disebutkan nama alMâturîdî sebagai seorang penafsir al-Qur'an. ${ }^{7}$

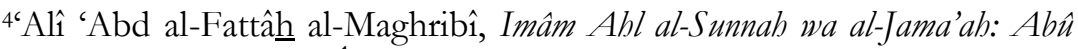
Manshûr al-Mâturîdî wa Ârâuh al-Kalamiyyah (Mesir: Maktabah Wahbah, 1985), 5 .

${ }^{5}$ Abû al-Khayr Muhammad Ayyûb 'Alî, 'Aqîdat al-Islâm wa al-Imâm al-AlMâturîdî (Bangladesh: al-Muassasah al-Islâmiyyah, 1983), 256.

'Lihat lampiran dalam kitab Ta'milat Abl al-Sunnab (Baghdad: al-Irsyâd, 1983), 693

${ }^{7}$ Al-Syirbâsî, ketika mengemukakan pembahasan tentang tingkatantingkatan para mufasir, tidak menyebutkan nama al-Mâturî̀î sebagai mufasir, tetapi dia justru menyebutkan nama tokoh Ahl al-Sunnah wa alJamâ'ah lain yang semasa dengan al-Mâturîdî, yaitu al-Asy'arî. Penyebutan nama al-Asy'arî sebagai mufasir juga diikuti oleh Muhammad Husayn alDzahabî di dalam al-Tafsîr wa al-Mufasirûn dengan mengatakan bahwa tafsir al-Asy’arî bernama al-Mukhtaz̧in. Shubhî Shâlih ketika menyebutkan namanama tafsir dan pengarangnya yang terdapat di kalangan Ahl al-Sunnah wa al-Jamâ'ah, juga tidak mencantumkan nama al-Mâturîdî maupun karya tafsirnya di dalam buku Mabâhits fì Ulûm al-Qur'ân. Hal yang sama ternyata dijumpai pula dalam buku Manâbil al-Irfân fì 'Ulûm al-Qur'ân karya Muhammad 'Abd al-'Azîm al-Zarqânî. Mannâ' al-Qaththân, Mabâhîts fî Ulûm

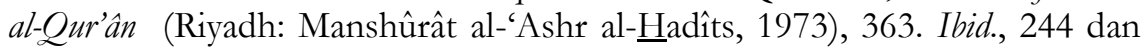




\section{Mengenal Profil Al-Mâturîdî}

Nama lengkapnya adalah Muhammad bin Muhammad bin Mahmûd Abû Manshûr al-Mâturîdî. Dia dilahirkan di Mâturîd atau al-Mâturit, sebuah daerah di Samarqand. ${ }^{8}$ Oleh karena dinisbahkan ke tempat inilah, maka nama yang disandangnya adalah al-Mâturîdî al-Samarqandî, meskipun terdapat tokoh lain yang juga menggunakan nama belakang al-Samarqandî. ${ }^{9}$ Nasab al-Mâturîdî secara genealogis termasuk nasab yang sangat terhormat karena apabila silsilahnya dirunut ke atas, maka akan sampai kepada Abû Ayyûb Khâlid bin Zayd bin Kulayb alAnshârî (w. 52 H/672 M), seorang sahabat berasal dari suku Khazraj di Madinah yang rumahnya pernah disinggahi Nabi Saw. ketika terjadi peristiwa hijrah dari Mekkah ke Madinah. ${ }^{10}$

Ahmad Amîn, Zubr al-Islâm, vol. 01 (Kairo: Lajnat al-Ta'lîf wa al-Tarjamah wa al-Nashr, 1952), 265.

8Ibid., 244 dan Aṇmad Amîn, Zubr al-Islâm, vol. 1 (Kairo: Lajnat al-Ta'lîf wa al-Tarjamah wa al-Nashr, 1952), 265.

${ }^{9}$ Nama al-Mâturîdî ternyata tidak hanya melekat pada tokoh yang sedang dikaji dalam tulisan ini. Terdapat nama al-Mâturî̀î lain, yaitu Ismâ'̂̂l Abû Manshûr al-Mâturî̀î yang disebut-sebut mempunyai kitab Syarh al-Fiqh alAbsath karya Abû Hanîfah, serta Risâlah Ushûl al-Îmân, dan Risâlah Fary Abl al-Dlalâl wa Maqâlâtibim yang keduanya masih berupa manuskrip di Universitas Kairo. Al-Maghribî, berdasarkan penelusuran yang dilakukannya, mengambil kesimpulan bahwa Ismâ'îl Abû Manshûr al-Mâturîdî ini adalah termasuk anggota keluarga dari al-Mâturîdî karena sama-sama menggunakan nama Abû Manshûr al-Mâturî̀î. Al-Maghribî, Imâm..., 14. Lihat pengantar tafsir al-Samarqandi, 8.

${ }^{10} \mathrm{Al}$-Maghribî, Imâm..., 12. Para pengikut al-Mâturîdî memberikan beberapa gelar kehormatan kepadanya, di antaranya adalah Imâm al-Hudâ (pemimpin pembawa petunjuk), Qudwat Abl al-Sunnah wa al-Ihtidâ' (panutan orang-orang yang mengikuti sunnah dan petunjuk), Râfi' A'lâm al-Sunnah wa al-Jamâ'ah (pembawa panji-panji Ahl al-Sunnah wa al-Jamâ'ah), Qâli' Adhâlîl al-Fitnah wa al-Bid'ah (penghapus kesesatan-kesesatan fitnah dan bid'ah),

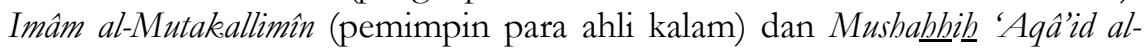
Muslimîn (pengoreksi akidah kaum muslimin). Gelar-gelar tersebut menunjukkan betapa tinggi kedudukan al-Mâturîdî dalam perspektif 
Para sejarawan tidak begitu banyak yang menjelaskan tahun kelahiran al-Mâturîdî, meskipun tampaknya mereka hampir seluruhnya sepakat untuk mengatakan bahwa al-Mâturîdî meninggal dunia pada $333 \mathrm{H} / 944 \mathrm{M}$ dan dimakamkan di Samarqand. Hanya sebagian kecil saja dari kalangan penulis yang berpendapat lain; Thâsy Zâdah yang menyebutkan bahwa alMâturîdî meninggal pada 332 H/943 M atau 336/947 M. ${ }^{11}$

Untuk mempermudah perkiraan terhadap tahun kelahiran alMâturî̀î, maka pembahasan masalah tersebut dihubungkan dengan tahun ketika guru-gurunya meninggal dunia; Nushayr bin Yahyâ al-Balkhî (w. 268 H/881 M) dan Muhammad bin Muqâthil al-Râzî (w. 248 H/862 M). Kemudian dari sini diperkirakan bahwa al-Mâturîdî kemungkinan besar dilahirkan sebelum $248 \mathrm{H} / 862 \mathrm{M}$. Apabila dia sewaktu menuntut ilmu setamat dari sekolah dasarnya berumur sekitar 10 tahun dan kemudian langsung berguru kepada Muhammad bin Muqâthil alRâzi, maka setidak-tidaknya dia dilahirkan tahun 238 H/852 M. Jika perkiraan ini dibenarkan, berarti dapat disimpulkan bahwa dia mempunyai usia yang cukup panjang, yaitu 92 tahun. Berangkat dari perkiraan itu pula, dapat dikatakan bahwa alMâturî̀î dilahirkan pada masa pemerintahan Khalifah alMutawakkil (232-247 H/846-861 M) dan pada saat terjadi pembunuhan terhadap al-Mutawakkil pada $248 \mathrm{H} / 862 \mathrm{M}$, alMâturî̀î berumur 9 tahun. Al-Mâturî̀î meninggal dunia pada masa pemerintahan Khalîfah al-Muttaqî bin al-Muqtadir (329$333 \mathrm{H} / 940-944 \mathrm{H}) .^{12}$

keilmuan di kalangan ulama-ulama lainnya. Tetapi di antara para penulis Barat ada yang menyebut al-Mâturî̀î sebagai The Second Great "Father" of Sunnite Theology (pemimpin besar II teologi Sunni) atau The Second Great Theologian of the Sunnite (teolog besar Sunni II) karena posisi al-al-Mâturîdî ditempatkan setelah al-Asy'arî.

${ }^{11}$ Ibid., 14.

12'Alî, 'Aqîdah..., 265. 
Dengan demikian, dia dilahirkan 22 tahun sebelum kelahiran al-Asy'arî (w. $330 \mathrm{H} / 941 \mathrm{H}$ ). Ini berdasarkan informasi yang menerangkan bahwa al-Asy'arî dilahirkan pada $260 \mathrm{H} / 873 \mathrm{M},{ }^{13}$ meskipun menurut keterangan lain, dia dilahirkan pada 270 H/883 M. ${ }^{14}$ Jika tahun $260 \mathrm{H} / 873 \mathrm{M}$ yang dipilih, maka alAsy'arî sebenarnya baru mulai memberikan kontribusinya terhadap penegakan mazhab Ahl al-Sunnah wa al-Jamâ'ah pada 300 H/912 M karena dia meninggalkan gurunya, Abû 'Alî Muhammad al-Jubbâî (w. 303 H/915 M), dan menyampaikan pernyataan keluar dari mazhab Mu'tazilah pada usia 40 tahun. ${ }^{15}$ Sedangkan al-Mâturîdî, yang semenjak dilahirkan pada 238 $\mathrm{H} / 852 \mathrm{M}$ diketahui tidak pernah keluar dari mazhab Ahl alSunnah wa al-Jamâ'ah, berperan dalam penegakan mazhab Ahl al-Sunnah wa al-Jamâ'ah sebelum tahun 300 H/912 M. Ini seandainya al-Mâturîdî menuntut ilmu selama kurang lebih 30-40 tahun. Disebutkan bahwa al-Mâturîdî setidak-tidaknya pernah menuntut ilmu kepada empat orang ulama yang secara kronologis rantai transmisi keilmuannya bersambung sampai kepada Abû Hanifah (w. 150 H/767 M). Empat orang ulama tersebut adalah Abû Bakr Ahmad al-Juzjânî, ${ }^{16}$ Abû Nashr Aḥmad al-'Tyâdî, Muhammad bin Muqâtil al-Râzî (w. 248 H/802 M) dan Nushayr bin Yahyâ al-Balkhî (w. 268 H/881 M). ${ }^{17}$

${ }^{13}$ Mûsâ, Nasy'at ..., 165.

${ }^{14}$ Abû Bakr bin Aḥmad bin Muhammad bin Muhammad bin Qâdî Syuhbah, Thabaqât al-Syâfi'iyyah, vol. 2. (Beirut: 'Âlam al-Kutub, 1986), 113.

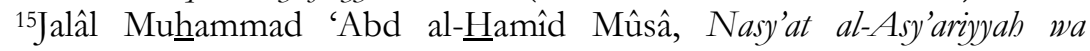
Tathawwuruhâ (Beirut: Dâr al-Kutub al-Lubnânî, 1975), 168.

${ }^{16} \mathrm{Al}$-Jûzjânî adalah suatu nama yang dinisbatkan kepada kota Jûzjân di Turkistan, Afghanistan, yang terletak di antara Murghâb dan Âmûdariyâ. Dengan demikian, ia berbeda dengan Jurjân (dulu bernama Astarâbâd) yang merupakan salah satu kota di Iran. Lihat Tawtal, al-Munjid..., 199.

${ }^{17}$ Lihat lampiran dalam kitab Ta'wîlât ..., 693. Selama masa hidupnya, alMâturî̀î meninggalkan karya-karya ilmiah bernilai tinggi yang berkaitan dengan ilmu-ilmu keislaman, seperti ilmu kalam, ushul al-fiqh dan tafsir. Menurut keterangan yang tertera dalam lampiran kitab Ta'mîlât Abl al- 


\section{Menyelami Kompetensi Al-Mâturîdî dalam Ranah Tafsir: Pengkombinasian antara Sumber Naqlî dan 'Aqlî}

Berdasarkan sumber penafsiran yang dipergunakan mufasir, tafsir dapat diklasifikasikan menjadi tiga macam: tafsîr bi al-ma'tsûr (tafsîr bi al-riwwayah atau tafsîr bi al-manqûl), tafsîr bi al-ray (tafsîr bi aldirâyah atau tafsîr bi al-ma'qûl), dan tafsîr bi al-iədiwâjj (perpaduan antara bi al-ma'tsîr dan bi al-ra'y). ${ }^{18}$ Apabila sumber-sumber penafsiran tafsir al-Mâturîdî dianalisis dengan seksama, maka akan sampai pada pernyataan bahwa langkah pengkombinasian antara sumber-sumber naqlî dan 'aqlî merupakan karakteristik paling menonjol di antara beberapa karakteristik yang terdapat di dalam tafsir tersebut. Sumber-sumber naqlî meliputi al-Qur'an, Sunnah Nabi, riwayat para shahabat $\mathrm{Nabi}$, dan riwayat para tâbi'în. Sedangkan sumber aq $\hat{\imath}$ adalah hasil ijtihad (pendayagunaan potensi akal). Berikut ini adalah contohnya ayat al-Qur'an yang artinya: "Dan di antara manusia ada yang

Sunnah, jumlah karya yang dihasilkan al-Mâturîdî sebanyak 24 karya, yaitu 2 dalam ilmu tafsir dan ilmu tajwid, 4 dalam ilmu figh, 12 dalam ilmu kalam, 1 dalam ilmu tasawuf, dan 5 sisanya dalam topik-topik lain yang beraneka ragam. Penyebutan yang tampaknya relatif lebih lengkap dilakukan oleh alMaghribî yang menyebutkan 15 karya: Kitâb al-Jadal, Kitâb Ma'khad al-Syarâi', Kitâb al-Tawhîd, Kitâb al-Maqâlât, Kitâb al-Radd 'alâ al-Qarâmithah, Kitâb Bayân Wabm al-Mu'tazilah, Kitâb Radd al-Ushûl al-Khamsah li Abî Munammad al-Bâbilî,

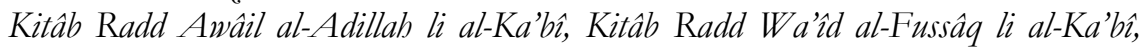
Kitâb Radd Tahdzî́b al-Jadal li al-Ka'bî, Kitâb Radd al-Imâmah li Ba'dh al-Rawâfidh, Kitâb al-Ushûl, Ta'wilât al-Qur'ân atau Ta'wîlât Abl al-Sunnab, Risâlah fî mâ lâ yajùz al-Waqf fîh fì al-Qur'ân al-Karim dan Kitâb Muqtathafât fi al-Wa'z: 'Ali, 'Aqîdah..., 273-8 dan al-Maghribî, Imâm ..., 28.

${ }^{18}$ Tafsîr bi al-ma'tsûr (tafsîr bi al-riwayah atau tafsîr bi al-manqûll) yaitu tafsir yang didasarkan pada sumber penafsiran dari al-Qur'an, riwayat para sahabat, dan para tâbi în; tafsîr bi al-ra'y (tafî̀r bi al-dirâyah atau tafî̀r bi almanqûl) yaitu tafsir yang didasarkan pada ijtihad dan pemikiran mufasir yang telah memenuhi syarat serta mempunyai kapabilitas mumpuni; tafsîr bi alizqdiwâj yaitu tafsir yang didasarkan pada pengkombinasian antara tafsîr bi alma'tsûr dan tafsir bi al-ra'y. Lihat Abdul Djalal, Urgensi Tafsir Maudlu'i Pada Masa Kini (Jakarta: Kalam Mulia, 1990), 64-8. 
mengatakan: 'Kami beriman kepada Allah dan hari akhir (kiamat), padahal mereka itu sesunggubnya bukan orang-orang yang beriman" (Qs. al-Baqârah [2]:8).

Kata "bi mu'minîn" (orang-orang yang beriman) dalam ayat ini berarti "bi mushaddiqîn bi qulübibim" (orang-orang yang membenarkan dengan hati mereka), sesuai dengan ayat yang artinya: "Hai Rasul, janganlah kamu merasa bersedih hati dikarenakan orang-orang yang bersegera (memperlibatkan) kekafirannya, yaitu di antara orang-orang yang mengatakan dengan mulut mereka: "Kami telah beriman", padahal hati mereka belum beriman" (Qs. al-Mâidah [5]:41). Dalam ayat lain, Allah juga berfirman yang artinya: "Maka demi Tubanmu, mereka (pada bakikatnya) tidak beriman bingga mereka menjadikan kamu sebagai hakim dalam perkara yang mereka perselisibkan, kemudian mereka tidak merasa berkeberatan di dalam hati terbadap putusan yang kamu berikan, dan mereka menerima dengan sepenubnya" (Qs. al-Nisâ' [4]:65). ${ }^{19}$

Adapun ketika melakukan penafsiran al-Qur'an, al-Mâturîdî juga berpedoman kepada hadis. Kesan menonjol yang ditangkap oleh setiap orang yang membaca tafsir al-Mâturî̀î adalah tidak dijumpainya penyebutan sanad hadis. al-Mâturîdî biasanya hanya menggunakan ungkapan-ungkapan, seperti: mâ ruwiya 'an al-nabiyy (hadis yang diriwayatkan dari Nabi Saw.), mâ ruwiya 'an rasûl Allahb (hadis yang diriwayatkan dari Rasulullah), kaqawlih shallâ Allâh 'alayh wa sallam (seperti sabda Nabi Saw.), li mâ ruwiya fî alkhabar (sebagaimana diriwayatkan dalam hadis), mâ jâ a 'an rasûl Allâh (hadis yang datang dari Rasulullah), dalîlub qawluh shallâ Allâh 'alayh wa sallam (dasar argumentasinya adalah sabda Nabi Saw.), wa fî ba'dh al-akhbâr (dan di dalam sebagaian hadis), mâ jâ'a fì al-khabar (dalil yang datang berupa hadis), dan dzukir fî̀ alkhabar (disebutkan dalam hadis). ${ }^{20}$

Oleh karena itu, sangatlah dimaklumi apabila terlontar pertanyaan mengenai latar belakang apa yang mendorong al-

${ }^{19}$ Al-Mâturî̀î, Ta'wîlât..., 42.

${ }^{20}$ Ibid., 8- 9, 226, 322, 385, 417, 479, 526 dan 634. 
Mâturî̀î untuk tidak menyebutkan sanad hadis di dalam tafsirnya, padahal sanad merupakan aspek penting yang tidak bisa diabaikan begitu saja dalam rangka mengetahui ke-shab $\underline{h} \underline{\underline{b}}$-an dan otentisitas hadis. Bahkan tindakan peniadaan sanad hadis yang sudah merebak di kalangan para mufasir pada masa sesudah tâbi' al-tâbìîn ini, menurut al-Dzahabî, mempunyai dampak negatif karena mengakibatkan al-wadb' (pemalsuan hadis) di dalam tafsir serta menimbulkan pencampuradukkan antara hadis shahît $\underline{\underline{b}}$ dan

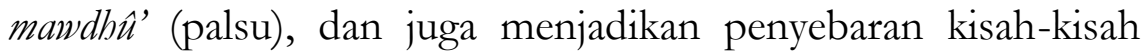
Isrâ'îliyyât semakin merajalela. ${ }^{21}$

Pertanyaan tersebut tentu tidak dapat terjawab secara pasti, karena yang mengetahui motivasi dan latar belakang tindakan seseorang pastilah hanya orang yang bersangkutan itu sendiri. Meski demikian, tidak salah apabila kita mencoba membuat perkiraan analisis. Kemungkinan besar al-Mâturîdî sengaja tidak menyertakan penyebutan sanad hadis karena dia tidak menginginkan perhatian para pembaca tafsirnya terlalu tersedot kepada hal-hal yang sifatnya tidak begitu signifikan, sehingga melupakan hal-hal yang lebih substantif. Di samping itu, alMâturîdî pasti telah mengetahui bahwa pada saat itu, sudah ada ulama-ulama lain yang memberikan perhatian khusus kepada bidang hadis dan bahkan mereka sudah berhasil membukukannya, seperti Abû 'Abd al-Lâh Muhammad al-

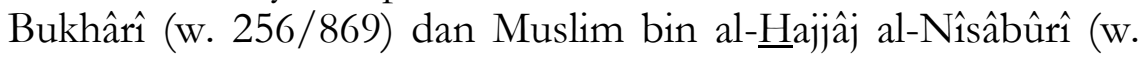
261/874) yang secara kebetulan tempat hidup keduanya (Bukhârâ dan Nishapur) terletak tidak jauh dari kota Samarqand, tempat kelahiran al-Mâturîdî. Contoh penafsirannya yang menggunakan hadis ialah terhadap ayat Al-Qur'an yang artinya: "Dan berdirilah (ketika melaksanakan shalat) karena Allab dengan keadaan khusyu" (Qs. al-Baqârah [2]:238).

Kata-kata "qânitîn" (dengan keadaan khusyu') dalam ayat ini dapat ditafsirkan dengan "khâsyi'în khâdhi'în" (dengan keadaan

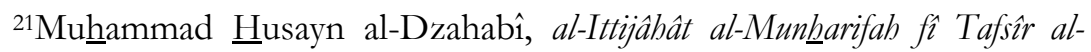
Qur'ân al-Karîm (Kuwait: Dâr al-I'tishâm, 1976), 14. 
khusyu' dan tunduk patuh) atau "muthî'în” (dengan ketaatan), karena secara semantis makna qunût adalah qiyâm (berdiri) berdasarkan jawaban Nabi Saw. ketika ditanya mengenai shalat yang paling utama. Saat itu Nabi Saw. menjawab: القنوت طول (shalat yang dikerjakan dengan berdiri lama), tetapi berdiri di sini tidaklah seperti berdiri pada umumnya, karena harus disertai dengan sikap ketundukan dan kekhusyu'an. ${ }^{22}$

Selain menyandarkan penafsiran kepada al-Qur'an, hadis, periwayatan shahabat Nabi Saw. dan tâbi'în, al-Mâturîdî juga menyandarkan penafsirannya kepada ijtihad. Contohnya adalah penafsirannya dalam ayat al-Qur'an yang artinya: "Tidak ada paksaan dalam menganut agama (Islam). Sesunggubnya telah jelas jalan yang benar dan jalan yang sesat. Oleh karena itu, barangsiapa mengingkari thaghut dan beriman kepada Allah, maka sesunggubnya dia telah berpegang kepada tali yang sangat kuat dan tidak akan putus. Dan Allah Maha Mendengar lagi Maha Mengetahui" (Qs. al-Baqârah [2]:256).

Al-Mâturî̀î, setelah menafsirkan "ikerâh" (paksaan) dengan

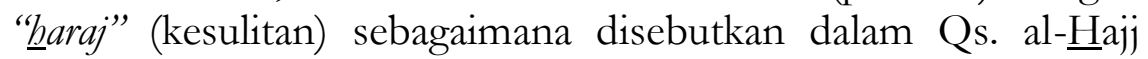
[22]:78, mengatakan bahwa "qad tabayyan al-rusyd min al-ghayy" berarti bahwa telah jelas antara Islam dan kekafiran, sehingga tidak ada paksaan dalam beragama. Sedangkan "thâghût" adalah segala hal yang dapat mengantarkan seseorang menuju penyembahan kepada selain Allah. Oleh karena itu, barangsiapa yang mengingkari thâgh $\hat{u}$ dan beriman kepada Allah, maka orang tersebut telah berpegang pada keyakinan kuat yang tidak tergoyahkan. Adapun "wa Allâh samî 'alîm” berarti bahwa Allah Maha Mendengar terhadap ucapan mereka dan Mengetahui pahala mereka atau Allah Maha Mendengar terhadap iman mereka dan Mengetahui balasan iman mereka. ${ }^{23}$

22Al-Mâturîdî, Ta'mîlât..., 559-60. Al-Jashshâsh menyebutkan hadis ini dengan sanad dari Nâfi' dari Ibn 'Umar.

23Ibid., 595-7. 


\section{Mempergunakan Analisis Kebahasaan secara Proporsional}

Sebagaimana diketahui bahwa di antara ilmu tafsir dan ilmu bahasa terdapat hubungan yang sangat erat. Seseorang untuk dapat diakui sebagai penafsir al-Qur'an, diharuskan memenuhi persyaratan-persyaratan dan menguasai ilmu-ilmu tertentu. Salah satu dari ilmu-ilmu yang dimaksudkan itu adalah ilmu bahasa.. ${ }^{24}$ Tuntutan untuk menguasai ilmu bahasa tampaknya tidaklah berlebihan, mengingat al-Qur'an adalah firman Allah yang diwahyukan kepada Nabi Muhammad Saw. dan dikomunikasikan kepada umatnya melalui sarana bahasa. Karena lingkungan masyarakat yang melingkupi Nabi Muhammad adalah masyarakat Arab, maka bahasa yang terpilih adalah bahasa Arab.

Demikianlah, seorang mufasir memang tidak mungkin menghindar dari ilmu bahasa Arab. Suka atau tidak suka, dia harus menceburkan diri untuk mempelajari dan menguasainya. Namun seorang mufasir yang penguasaan bahasa Arabnya telah mumpuni, dalam penerapannya kadang terlalu asyik dengan ilmu itu, sehingga mengakibatkan tafsir al-Qur'an terseret jauh ke dalamnya dan terjadilah penyimpangan-penyimpangan penafsiran..$^{25}$

Lantas, bagaimanakah sikap al-Mâturîdî di terhadap penggunaan ilmu bahasa di dalam menafsirkan al-Qur'an? Memang sebagai seorang mufasir, al-Mâturîdî sudah seharusnya melibatkan ilmu bahasa dalam rangka menjalankan tugasnya menerangkan kandungan al-Qur'an. Ilmu bahasa merupakan suatu alat yang fungsinya membantu mufasir untuk menafsirkan

\footnotetext{
${ }^{24}$ Perincian mengenai persyaratan-persyaratan dan ilmu-ilmu yang harus dimiliki mufasir dapat dilihat di al-Shabbâgh, Lamahât..., 192-5 dan alSuyûthî, al-Itqân fî̀ 'Ulûm al-Qur'ân, vol. 3 (Beirut: Muassasat al-Kutub alTsaqâfiyyah, 1996), 472-4.

${ }^{25}$ Contoh-contoh penyimpangan tafsir itu antara lain dapat dilihat di dalam al-Dzahabî, al-Ittijâhât..., 39-43.
} 
al-Qur'an. ${ }^{26}$ Oleh karena itu, sangatlah bisa dimaklumi apabila dia menggunakan ilmu bahasa, seperti ketika menjelaskan makna-makna kosa kata al-Qur'an, kedudukannya di dalam kalimat atau pola-pola pembentukannya. Namun, dia menerapkannya secara proporsional sesuai dengan keperluan sehingga di dalam tafsirnya tidak dijumpai pembahasanpembahasan kebahasaan yang mendalam maupun terperinci. Di samping itu, dia juga sangat jarang mencari pijakan argumentasi dengan syair-syair yang biasanya disertakan dalam analisisanalisis kebahasaan. Kemungkinan, tujuan utama yang ingin dicapai oleh al-Mâturîdî dengan langkah semacam itu adalah sekedar menunjukkan kepada para pembaca, bahwa penafsiran al-Qur'an yang disandarkan pada ilmu bahasa dapat diakui kebenarannya. Contoh penafsirannya ialah ayat al-Qur'an berikut yang artinya: "Apakah kamu menceritakan kepada mereka (orangorang beriman) apa yang telah diterangkan Allah kepadamu, supaya dengan demikian mereka dapat mengalabkan bujjahmu di hadapan Tuhanmu?" (Qs. al-Baqârah [2]:76).

Ungkapan "li yubâjjûkum ind rabbikum" (supaya dengan demikian mereka dapat mengalahkan hujjahmu di hadapan Tuhanmu) dapat ditafsirkan: (a) seolah-olah Allah mengatakan: "li yubâjjukkum bi iqrârikum ind rasûl Allâh" (supaya mereka dapat mengalahkan hujjahmu dengan pengakuan kamu di hadapan Rasulullah), (b) "yubâjjûkum fî̀ rabbikum" (supaya dengan demikian mereka dapat mengalahkan hujjahmu mengenai Tuhanmu) karena orang Arab biasanya memberi makna suatu preposisi dengan preposisi yang lain, dan (c) supaya dengan demikian mereka dapat mengalahkan hujjahmu pada hari kiamat. ${ }^{27}$

26al-Zarkasyî, al-Burhân fî 'Ulûm al-Qur'ân, vol. 01 (Beirut: Dâr al-Kutub al-'Ilmiyyah, 1988), 33.

${ }^{27}$ Al-Mâturîdî, Ta'wîlât..., 175. Contoh-contoh lain yang serupa dengan ini, di antaranya, terdapat di halaman 271 ('alâ berarti $l i-$ QS. 2:143), 436 ( $f$ i berarti bi-Qs. [2]:210), dan 633 (fî berarti min - Qs. [2]:264). 


\section{Tidak Terlalu Terikat dengan Asbâb al-Nuzûl}

Secara etimologis, asbâb al-nu₹̂ul bermakna sebab-sebab turun, karena asbâb adalah bentuk plural dari sabab yang berarti sebab, ${ }^{28}$ sedangkan nu₹ûl adalah kata benda berbentuk infinitive untuk kata kerja nazala-yanzilu yang berarti turun. ${ }^{29}$ Karena dalam konteks ini pendefinisiannya terkait dengan ayat-ayat al-Qur'an, maka asbâb al-nu₹ûl berarti sesuatu hal yang melatarbelakangi ayat al-Qur'an diturunkan, sehingga al-Qur'an dapat menerangkan hal itu pada saat peristiwa terjadi atau memberikan jawaban terhadap pertanyaan mengenai hal itu. ${ }^{30}$ Manfaat asbâb al-nu₹ûl terhadap penafsiran al-Qur'an sudah diakui oleh banyak penulis, ${ }^{31}$ meskipun mereka juga menyadari bahwa tidak semua ayat al-Qur'an turun dikarenakan adanya sebab-sebab tertentu, baik berupa peristiwa maupun pertanyaan. Al-Ja'barî mengatakan bahwa ayat-ayat al-Qur'an diklasifikasikan menjadi dua, yaitu ayat-ayat yang turun tanpa sebab dan ayat-ayat yang turun dengan didahului oleh sebab tertentu. ${ }^{32}$

Al-Mâturî̀î rupanya termasuk tipe mufasir yang mempunyai sikap tersendiri, yakni sikap berani untuk tidak terlalu terikat dengan asbâb al-nu₹̂̂l ketika melakukan penafsiran al-Qur'an. Dengan demikian, dia masih menggunakan asbâb al-nuðûl dalam batas-batas tertentu, sehingga tidak menyingkirkannya secara keseluruhan. Dia menggunakan asbâb al-nu₹ûl sebagai sarana untuk melakukan penafsiran terhadap ayat-ayat al-Qur'an. Sebagaimana dilakukan mayoritas ulama, dia ternyata lebih

\footnotetext{
${ }^{28}$ Louis Ma'lûf, Al-Munjid fî al-Lughah (Beirut: Dâr al-Masyriq, 1995), 316.

${ }^{29}$ Ibid., 802.

30Shâlih, Mabâhits..., 132, al-Zarqânî, Manâhil..., 106 dan al-Qaththân, Mabâhits..., 77-8.

${ }^{31}$ Perincian tentang manfaat asbâbal-nûzûl dapat dilihat, di antaranya, pada al-Zarkasyi, al-Burbân..., 45-6; Shâlih , Mabâhits...,129-131, al-Zarqânî, Manâbil..., 109-114 dan al-Qaththân, Mabâhits...,79-82.

32Al-Suyûtî, al-Itqân..., 94.
} 
mengutamakan untuk menerapkan kaidah al-ibrah bi umûm al-

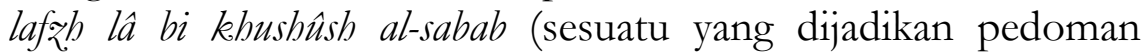
adalah keumuman lafaz, bukan kekhususan sebab). Berikut ini adalah contoh mengenai hal tersebut dalam ayat al-Qur'an yang artinya: "Hai orang-orang beriman, diwajibkan atas kamu qishas mengenai orang-orang yang dibunuh, orang merdeka dengan orang merdeka, budak dengan budak dan perempuan dengan perempuan" (Qs. al-Baqârah [2]:178).

Dikatakan bahwa ayat ini turun mengenai dua pasukan dari bangsa Arab yang terlibat dalam suatu peperangan. Status kedua pasukan itu berbeda, yang satu lebih terhormat daripada yang lain. Oleh karena itu, salah satunya menginginkan qishâs seorang budak dengan orang merdeka dan perempuan dengan lelaki. Maka kemudian Allah menurunkan surah al-Baqarah [2:178]. Tetapi karena di dalamnya terdapat pembunuhan kepada orang yang bukan pembunuh, maka ayat ini dinaskh (dihapus) oleh ayat yang artinya: "Dan janganlah kamu membunuh jiwa yang diharamkan Allah (membunuhnya), melainkan dengan suatu (alasan) yang benar. Dan barangsiapa dibunuh secara zalim, maka sesunggubnya Kami telah memberi kekuasaan kepada abli warisnya. Tetapi janganlah abli waris itu melampaui batas di dalam membunuh. Sesunggubnya dia adalab orang yang mendapatkean pertolongan" (Qs. al-Isrâ’ [17]: 33). ${ }^{33}$

Al-Mâturî̀î pada saat tertentu tidak terlalu terikat dengan asbâb al-nu₹̂̂ll ketika menafsirkan ayat-ayat al-Qur'an. Misalnya adalah terhadap ayat al-Qur'an yang artinya: "Dan mereka mengikuti apa yang dibaca oleh setan-setan di Kerajaan Sulaiman. (Mereka mengatakan babwa Sulaiman melakukan sibir), padahal Sulaiman itu tidak kafir (tidak. mengerjakan sibir). Hanya setan-setan itu saja yang kafir (mengerjakan sibir dan) mengajarkan sibir kepada manusia” (Qs. al-Baqârah [2]:102).

Dikatakan, ungkapan "mâ tatlù" (apa yang dibaca) mempunyai beberapa arti, yaitu [a] kitab-kitab sihir yang ditulis

${ }^{33} \mathrm{Al}$-Mâturîdî, Ta'wîlât..., 335. Dengan beberapa matn dan sanad berbeda al-Suyûthî menyebutkan al-Durr al-Mantsûr..., 260. 
oleh setan-setan, [b] bacaan-bacaan setan karena "tatlu’" berasal dari kata "tilâwah" (bacaan), dan [c] kitab-kitab sihir yang diriwayatkan (diceritakan) oleh setan-setan, sebagaimana pendapat Ibn 'Abbâs. Semua pendapat itu sebenarnya merujuk kepada satu maksud yang sama. Ayat ini digunakan sebagai argumentasi oleh orang-orang Yahudi yang menyangka bahwa apa yang mereka miliki berasal dari Sulayman. Seandainya mereka dianggap kafir, maka Sulayman juga termasuk kafir. Oleh karena itulah, Allah memberitahukan kepada Nabi Muhammad bahwa Sulayman tidak kafir, tetapi setan-setan itulah yang kafir. Ayat ini dapat dipahami pula bahwa para pengikut setan-setan itulah yang kafir, karena meyakini sihir dan menerapkan sihir yang diajarkan setan, sehingga kekafiran itu dinisbatkan kepada setan-setan, seperti perbuatan para penyembah berhala yang juga dinisbatkan kepada setan-setan itu.

Diriwayatkan dari Ibn 'Abbâs, bahwa seorang sekretaris Nabi Sulayman yang bernama Âshif senantiasa menulis segala hal atas perintah Sulayman dan memendam tulisan-tulisan itu di bawah singgasana Sulaiman. Pada saat Sulayman meninggal, setan-setan mengeluarkannya dan menyalinnya dengan menyisipkan sihir, kekafiran dan kedustaan dalam setiap dua baris. Mereka selanjutnya mengatakan kepada orang-orang bahwa itu semua adalah apa yang telah dilakukan Sulayman, sehingga orang-orang yang tidak mengetahui itu mengkafirkan Sulayman dan mencaci makinya. Demikianlah keadaan tersebut berlangsung sampai ayat "wa ittaba'û..." (dan mereka mengikuti ...) diturunkan Allah.

Sebagian orang mengatakan bahwa setan-setan itu merekayasa tulisan-tulisan sihir tersebut. Mereka kemudian menyebarluaskan dan mengajarkannya kepada masyarakat umum. Ketika Sulayman mendengar hal itu, dia menyelidikinya, merampasnya, dan memendamnya di bawah singgasananya karena takut dipelajari orang-orang itu. Setelah Sulayman meninggal, setan-setan itu selanjutnya mengambil dan mengeluarkannya. Oleh karena itu, Allah membebaskan 
Sulayman dari tuduhan kafir melalui lidah Nabi Muhammad Saw. dengan menurunkan ayat "wa mâ kafara Sulaymân ..." (dan Sulayman itu tidak kafir ...).

Dikatakan pula, bahwa orang-orang menderita berbagai penyakit setelah Sulayman meninggal. Mereka kemudian mengandaikan seumpama Sulayman masih hidup, pasti musibah itu teratasi. Setan-setan lalu menunjukkan apa yang pernah dilakukan Sulayman dengan menuliskannya dan menyimpannya di rumah-rumah mereka. Maka orang-orang itu mengeluarkan tulisan-tulisan sihir itu dan mereka mengatakan bahwa itu semua adalah perbuatan Sulayman. Oleh karena itu, Allah menurunkan ayat "wa mâ kafara Sulaymân..." (dan Sulayman itu tidak kafir...).

Selanjutnya al-Mâturî̀î mengatakan bahwa kisah sebenarnya tentang peristiwa itu tidaklah diketahui, tetapi yang secara jelas diketahui adalah bahwa orang-orang Yahudi telah meninggalkan kitab-kitab para Rasul dan mengikuti kitab-kitab setan yang berisi kekafiran dan sihir tersebut. Di samping itu, dalam ayat itu terkandung petunjuk risalah kenabian Muhammad Saw. yang dengan izin Allah, Nabi dapat memberitahukan kepada orangorang Yahudi mengenai kisah mereka dan membebaskan Sulayman dari tuduhan kafir. ${ }^{34}$

Dengan memberikan komentar penutup itu, al-Mâturîdî hendak menegaskan bahwa riwayat-riwayat tentang kisah tersebut belum tentu mengandung kebenaran. Seolah-olah dia melontarkan himbauan kepada para pembaca tafsirnya supaya bersikap hati-hati terhadap kisah-kisah semacam itu, meskipun di dalamnya terkandung informasi mengenai asbâb al-nu₹ûul.

\section{Menjelaskan Keanekaragaman Qirâ'ah}

Qirâ'ah secara etimologis adalah kata benda berbentuk infinitive untuk kata kerja qara'a-yaqra'u yang berarti bacaan. ${ }^{35}$

${ }^{34}$ Ibid., 202-3.

35Ma'lûf, al-Munjid..., 616. 
Sedangkan secara terminologis, qirâ'ah adalah suatu mazhab dari seorang imam pembaca al-Qur'an yang berbeda dari mazhab lainnya dalam hal pengucapan ayat-ayat al-Qur'an dengan disertai persesuaian antara riwayat-riwayat dan jalur-jalur penyampaiannya, baik perbedaan tersebut menyangkut pelafalan huruf atau pelafalan hal-hal lainnya. ${ }^{36}$ Dengan demikian, qira'ah bukanlah salah satu dari "tujuh huruf" (sab'ah a a disabdakan Nabi Muhammad Saw. dalam hadisnya: "Sesungguhnya al-Qur'an ini diturunkan di atas tujub huruf." Meskipun semua penulis sepakat mengenai kemutawatiran hadis ini, karena jumlah para shahabat Nabi Saw. yang meriwayatkannya mencapai 21 orang, tetapi mereka berselisih pendapat mengenai makna sab'ah a $\underline{h} r u f$. Menurut perhitungan, jumlah pendapat itu sekitar 35 atau 40, dan satu pendapat dengan lainnya tidak terdapat kesamaan. ${ }^{37}$ Dari sekian banyak pendapat tersebut, yang paling tepat adalah pendapat yang mengatakan bahwa sab'ah abruf adalah tujuh aspek perbedaan yang terdapat di antara qira'ah-qira'ah yang ada. Dinilai sebagai pendapat paling tepat karena mampu mengakomodir perbedaan-perbedaan bacaan yang kadang jumlahnya sangat banyak dan beraneka ragam. ${ }^{38}$

Jika keanekaan qirâ'ah adalah demi memberikan kemudahan kepada umat dalam berkomunikasi dengan al-Qur'an ${ }^{39}$ itu sudah diakui oleh semua pihak, maka bagaimanakah sikap para mufasir terhadapnya? Hampir dapat dipastikan bahwa sebagian besar mufasir mempunyai kecenderungan untuk menampilkan dan menjelaskan perbedaan-perbedaan yang terdapat di dalam qira'ah-qirâ'ah tersebut, di antaranya al-Mâturîdî.

36al-Zarqânî, Manâhil..., 412.

${ }^{37}$ Ibid., 178; al-Suyûthî, al-Itqân..., 129-130, dan al-Shabbâgh, Lamabâat..., 170 .

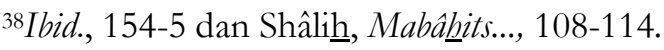

${ }^{39}$ Uraian mendetail mengenai manfaat keanekaragaman qirâ'ah, di antaranya dapat dilihat di al-Zarqânî, Manâhil...,146-9 dan al-Qaththân, Mabâhith..., 169. 
Al-Mâturîdî kadang mengemukakan perbedaan qirâab hanya secara sekilas, tanpa penjelasan terperinci, tetapi dalam ayat-ayat lain dia memberikan pemaparan secara panjang lebar. Di samping itu, dia tidak pernah memberikan penilaian mengenai status masing-masing qira'ah yang dikemukakan di dalam tafsirnya. Sebagaimana biasanya, al-Mâturî̀î ketika mengemukakan perbedaan qira'ah tidak selalu menyertakan pihak-pihak yang menjadi sumber qira'ah. Di antara sumbersumber qirâ'ah dari kalangan sahabat Nabi Saw. yang disebutkan dengan jelas adalah 'Abd Allâh bin Mas'ud (w. 32/652), 'Abd Allâh bin 'Abbâs (w. 68/687), Ubayy bin Ka'b (w. 31/651). Sedangkan dari kalangan tâbi'în adalah al-Hasan al-Bashrî (w. 110/728), dan Muqâtil bin Sulaymân (w. 150/767). Contohnya adalah dalam ayat al-Qur'an yang artinya: "Maka seandainya mereka beriman kepada sesuatu seperti apa yang kamu imani, sungguh mereka telah mendapatkan petunjuk." (Qs. al-Baqârah [2]:137).

Diriwayatkan dari "Abd al-Lâh bin "Abbâs, bahwa dia melakukan pelarangan untuk membacanya dengan "fa in âmanû bi mitsl mâ âmantum bih", sehingga dia memerintahkan supaya

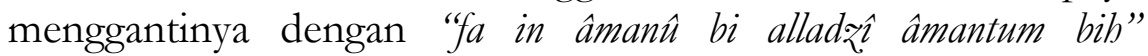
(beriman kepada apa yang kamu imani). Bacaan serupa juga dibenarkan oleh 'Abd Allâh bin Mas'ûd.

\section{Berhati-hati terhadap Kisah-kisah Isrâ'îliyyât}

Isrấlilyyât ditinjau dari sisi etimologis adalah bentuk plural dari kata isrâ'îliyyah, sebuah kata yang dinisbatkan kepada Isrầ̂l (julukan Nabi Ya'kûb) dan anak-anak keturunannya. Anak-anak keturunan Isrâ'îl ini terdiri dari dua golongan, yaitu Yahudi dan Nasrani. Mereka itulah yang dalam perjalanan waktu selanjutnya dikenal dengan sebutan ahli kitab. Sedangkan ditinjau dari sisi terminologis, isrầiliyyât adalah suatu kata yang dipergunakan untuk menunjuk kepada kisah-kisah dan dongeng-dongeng yang disandarkan kepada sumber-sumber Yahudi atau Nasrani, yaitu kitab Taurat dan kitab Injil. Sebagian besar dari kisah-kisah 
isrâ'îliyyât mempunyai kaitan dengan kisah-kisah masa lampau dan peristiwa-peristiwa yang dialami para Nabi terdahulu. Karena sumber-sumbernya adalah kitab Taurat dan kitab Injil yang secara faktual telah tercemari oleh campur tangan manusia, maka kisah-kisah isrầîliyyât tidak dapat terhindar dari kerancuan, ketidakakuratan dan kedustaan ${ }^{40}$

Berdasarkan kuantitas periwayatannya terhadap kisah-kisah isrâ'îliyyât, para mufasir terbagi menjadi dua kelompok di dalam menyikapi kisah-kisah Isrầilliyyât, yaitu [1] kelompok yang banyak meriwayatkan kisah-kisah isrấlilyyyât, seperti Muhammad bin Jarîr al-Thabarî (w. 310/923), dan [2] kelompok yang sedikit meriwayatkan kisah-kisah isrâ'îliyyât, seperti al-Hâfiz Ismâ'îl bin Katsîr (w. 774/1372). ${ }^{41}$ Al-Mâturîdî dapat dikategorikan ke dalam kelompok kedua yang sedikit meriwayatkan kisah-kisah isrâ'îliyyât dan sangat berhati-hati dalam menyikapinya. Pada saat berjumpa dengan ayat-ayat yang mengandung kisah-kisah masa lampau, seperti kisah-kisah yang terkait dengan para nabi terdahulu, al-Mâturîdî memang menuturkan kisah-kisah tersebut berdasarkan pendapat atau periwayatan berbagai pihak, tetapi di penghujung penuturannya, dia seringkali menyatakan keraguraguannya mengenai kebenaran yang terkandung di dalam kisahkisah tersebut, sehingga dia tidak dapat meyakininya secara pasti.

Di samping itu, al-Mâturîdî senantiasa mengatakan bahwa keinginan untuk mengetahui kisah-kisah tersebut secara mendetail, sebenarnya merupakan sikap yang berlebih-lebihan dan tidak ada faedahnya seandainya dilakukan. Bagi al-Mâturîdî,

${ }^{40}$ Muhammad bin Muhammad Abû Syuhbah, al-Isrâ'îliyyât wa alMawdlûât fî Kutub al-Tafsîr (Kairo: al-Hay'ah al-'Âmmah li Syu'ûn alMathâbi’ al-Amîriyyah, 1973), 21; Muhammad Husayn al-Dzahabî, al-

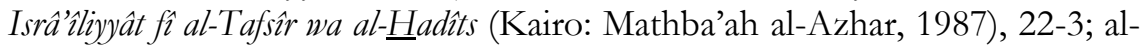
Dzahabî, al-Tafsîr wa al-Mufasirûn..., 165-9, dan 'Abd al-Wahhâb Fâyd, Manhaj Ibn 'Athiyyah fì Tafsîr al-Qur'ân al-'Azîm (Kairo: Al-Hay'ah al-'Âmmah li Syu'ûn al-Mathâbi' al-Amîriyyah, 1973), 178.

${ }^{41}$ Fâyd, Manhaj..., 181. 
penyampaian kisah-kisah yang tidak terperinci di dalam alQur'an sudah cukup untuk dijadikan bukti yang menunjukkan bahwa risalah kenabian Muhammad Saw. adalah benar-benar berasal dari Allah. Muhammad tentu sangat mustahil dapat mengetahui kisah-kisah yang terdapat di dalam kitab Taurat maupun kitab Injil, apabila tidak mendapatkan petunjuk dari Allah. Berikut ini adalah contoh-contoh yang menjelaskan sikap al-Mâturîdî tersebut.

Al-Mâturîdî menyampaikan kisah yang berkenaan dengan Tâbût tanpa menjelaskan sumber periwayatannya ketika memberikan penafsiran terhadap ayat: "Dan Nabi mereka mengatakan kepada mereka, sesunggubnya tanda bahwa dia akan menjadi raja adalah kembalinya Tâbût kepada kalian yang di dalamnya terdapat sakinah dari Tuban kalian" (Qs. al-Baqârah [2]:248).

Disebutkan bahwa Tâbût sebenarnya berada di tangan para Nabi. Setiap kali Bani Isra'il berperang, mereka mempertunjukkan Tâbût yang ada pada mereka tersebut di hadapan musuh, dan dengan perantaraan itu mereka memohon kemenangan dalam peperangan. Di dalam Tâbût terdapat sakînah yang bentuknya seakan-akan mirip kepala seekor kucing yang dapat mengeluarkan rintihan keras ke arah musuh. Sewaktu sakinah itu merintih, mereka berjalan beriringan bersama Tâbût itu, tetapi sewaktu sakinah itu tidak merintih, mereka berhenti dan tetap berada di belakangnya. Karena Bani Isra'il berbuat durhaka kepada para Nabi yang diutus kepada mereka, maka dengan kehendak Allah, mereka dapat dikalahkan oleh musuh dan Tâbût yang ada dirampas musuh. Kemudian setelah perjalanan waktu yang cukup lama, Tâbût itu dikembalikan kepada mereka. Peristiwa kembalinya Tâbût inilah yang dijadikan oleh Allah sebagai tanda bahwa Tâbût akan menjadi raja bagi mereka. Demikianlah kisahnya, tetapi kita tidak mengetahui dengan sebenar-benarnya mengenai perincian kisah tersebut.

Al-Mâturîdî melanjutkan bahwa di dalam penafsiran kata "sakinah" terdapat perselisihan pendapat, yaitu: [a] "sakînab" 
adalah angin kencang yang di dalamnya terdapat gambar seperti wajah seorang manusia, [b] "sakinah" adalah seekor kucing bersayap dua yang apabila bersuara, maka orang-orang Bani Isra'il mengetahui bahwa mereka telah memperoleh kemenangan, [c] "sakinah" adalah tetesan-tetesan emas berasal dari surga yang dipergunakan untuk membersihkan hati para Nabi, dan [d] "sakinah" adalah ketenangan yang didapat dari Tuhan, karena dengan adanya Tâbût tersebut, hati mereka senantiasa menjadi merasa tenang dan tentram di manapun mereka berada. Al-Mâturî̀î menutup pemaparannya dengan mengatakan, bahwa kita tidak mengetahui secara pasti apa yang sebenarnya dimaksud dengan kata "sakinah" dalam ayat ini, tetapi kita hanya mengetahui bahwa hati Bani Isra'il merasa tenang dan tentram berkat keberadaan Tâbût itu di sisi mereka. Oleh karena itu, tidak ada keperluan bagi kita untuk mengetahui hakikat "sakînah" yang sesungguhnya. ${ }^{42}$

\section{Mengutamakan Jalan Tengah dalam Permasalahan Teologis}

Di dalam literatur-literatur yang membahas sejarah perkembangan teologi Islam, sering disebutkan bahwa perpecahan yang terjadi di dalam tubuh umat Islam sudah diprediksikan oleh Nabi melalui hadis-hadisnya. Diriwayatkan dari Abû Hurayrah, bahwa Nabi Saw. bersabda: "Umat Yahudi telah terpecah menjadi 71 golongan, umat Nasrani telah terpecah menjadi 72 golongan, sedangkan umatku akan terpecah menjadi 73 golongan." Diriwayatkan dari 'Abd Allah bin "Amr bin alA < sh, bahwa Nabi bersabda: "Niscaya akan terjadi pada umatku apa yang terjadi pada Bani Isra'il. Bani Isra'il telah terpecah menjadi 72 golongan, dan umatku akan terpecah menjadi 73 golongan. Semuanya berada dalam neraka, kecuali satu golongan. Mereka bertanya; "Wahai Rasulullah, siapakah satu golongan

42Al-Mâturîdî, Ta'mîlât..., 575-6. 
yang dikecualikan itu? Rasulullah menjawab: Golonganku dan para shahabatku." Diriwayatkan dari Anas bin Mâlik, bahwa Rasulullah bersabda: "Bani Isra'il telah terpecah menjadi 71 golongan, dan umatku akan terpecah menjadi 72 golongan. Semuanya berada dalam neraka, kecuali satu golongan, yaitu alJamâ'ah."43

Berdasarkan penelusuran terhadap kitab Ta'wîlât Abl alSunnah dan Kitâb Tawhî́d-nya, dapat dinyatakan bahwa al-Mâturîdî merupakan seorang mutakallim atau teolog dan sekaligus mufasir yang mengutamakan jalan tengah dalam menyikapi perbedaan pendapat di antara mazhab-mazhab teologi. Sikap tawassuth (mengambil jalan tengah) inilah yang menempatkan mazhab Ahl al-Sunnah wa al-Jamâ'ah aliran Mâturîdiyyah pada posisi moderat yang tidak bersifat ekstrim. Sikap demikian ternyata juga ditempuh oleh aliran Asy'ariyyah, meskipun secara komparatif di antara kedua aliran itu terdapat perbedaanperbedaan kecil yang sifatnya tidak prinsipil, karena hanya berkenaan dengan persoalan-persoalan furû'iyyah semata. ${ }^{44}$ Berikut ini adalah contoh pemikiran teologi al-Mâturîdî tersebut.

Râfidlah berpendapat bahwa Rasulullah dan 'Alî bin Abî Thâlib dapat memberikan syafâ'ah (pertolongan) kepada orang Islam yang berdosa maupun orang kafir tanpa seizin Allah. Mu'tazilah berpendapat bahwa orang Islam yang berdosa maupun orang kafir tidak mendapatkan syafâ'ah. Al-Asy'arî berpendapat bahwa orang Islam yang berdosa mendapatkan syafâ'ah Rasulullah. ${ }^{45}$ Sedangkan al-Mâturîdî berpendapat bahwa orang Islam yang berdosa mendapatkan syafấah Allah dan RasulNya karena mereka pernah taat kepada Allah, apalagi jika mereka

${ }^{43}$ Abd al-Qâhir al-Baghdâdî, Al-Farq Bayn al-Firaq (Beirut: Dâr alKutub al-'Tlmiyyah, tt.), 5-7.

${ }^{44}$ Lihat pengantar Kitâb al-Tawhîid...,11-3.

${ }^{45}$ Abû al-Qâsim 'Alî bin Hibat Allâh Ibn 'Asâkîr, Tabyîn Kadžib al-Muftarâ (Beirut: Dâr al-Kutub al-'Arabî, 1983), 151. 
mau melakukan tawbat, tetapi syafâ'ab itu hanya terbatas kepada orang Islam saja, bukan diperuntukkan bagi orang kafir. ${ }^{46}$

\section{Mengikuti Mazhab Hanafí dalam Melakukan Istinbâth Hukum}

Berdasarkan penelusuran terhadap tafsir al-Mâturî̀î, dapat dinyatakan bahwa apabila ditinjau dari sisi kuantitas, maka pembahasan mengenai âyât al-abkâm (ayat-ayat hukum) yang terdapat di dalam tafsir tersebut tidak bersifat mendetail. Istinbâth hukum yang dilakukan al-Mâturîdî lebih banyak diarahkan pada ayat-ayat yang sedang dihadapinya saja dengan tidak mengembangkannya secara panjang lebar ke dalam persoalanpersoalan juz'iyyah (parsial terperinci). Hal itu kemungkinan disebabkan oleh fokus perhatian al-Mâturîdî yang sejak permulaan penyusunan tafsirnya tidak hanya terpusat pada ayatayat hukum semata, melainkan menyebar kepada keseluruhan ayat dengan tanpa memilah-milahnya sesuai dengan kandungan materi di dalamnya.

Oleh karena itu, secara komparatif tafsir al-Mâturîdî sangat berbeda dengan tafsir A $\underline{b} k a ̂ m$ al-Qur'ân karya Abû Bakr A $\underline{\text { hmad }}$ al-Râzî al-Jashshâsh yang dikhususkan hanya membahas ayatayat hukum dengan pemaparan mendetail, meskipun keduanya sama-sama menganut mazhab Hanafî dalam penerapan hukumhukum fiqh. Dengan pertimbangan inilah, maka merupakan suatu kewajaran apabila tafsir A $\underline{h k a m}$ al-Qur'ân dinilai sebagai sebuah tafsir yang representatif untuk dijadikan referensi bagi setiap orang yang ingin mengetahui lebih mendalam mengenai persoalan-persoalan hukum fiqh dalam mazhab $\underline{H}$ anafî.

Di samping itu, al-Mâturîdî ternyata lebih cenderung untuk mengikuti mazhab $\underline{H}$ anafî dalam melakukan istinbath hukum. Kecenderungan tersebut sangat kelihatan ketika hasil-hasil istinbâth hukum yang dilakukan al-Mâturîdî dikomparasikan

46Al-Mâturîdî, Ta'wîlât..., 590-1 dan Kitâb al-Tawhîid..., 365-6. 
dengan istinbâth hukum yang dilakukan kelompoknya. Komparasi itu menunjukkan bahwa di antara hasil-hasil istinbâth hukum mereka sebenarnya terdapat banyak persamaan. Berikut ini adalah sebagian dari contoh persamaan tersebut. Dengan menyandarkan argumentasi pada dalil-dalil yang tidak jauh berbeda, baik al-Mâturîdî maupun kelompok mazhabnya samasama mengatakan bahwa lafadz "basmalah" merupakan ayat alQur'an, tetapi ia bukan merupakan bagian integral dari surat alFâtihahah ${ }^{47}$ dan menunaikan shalat tanpa disertai dengan bacaan surat al-Fâtihah tidak batal dan tetap dihukumi sah. ${ }^{48}$

Semua narasi di atas meneguhkan fakta bahwa al-Mâturîdî (dalam kapasitasnya sebagai penafsir al-Qur'an, bukan teolog) memiliki keunikan tersendiri dalam menguraikan kandungan makna al-Qur'an.

\section{Catatan Akhir}

Berdasarkan pemaparan di atas, dapat dinyatakan bahwa alMâturî̀î merupakan seorang ulama yang telah memenuhi kualifikasi sebagai mufasir dan mempunyai kompetensi tinggi di bidang tafsir. Metode penafsirannya di antaranya ialah mengkombinasikan antara sumber-sumber naqlî (al-Qur'an, sunnah Nabi, riwayat para shahabat Nabi serta tâbi'în) dan 'aqli, mempergunakan analisis kebahasaan secara proporsional sesuai dengan keperluan tanpa sikap berlebih-lebihan, tidak terlalu terikat dengan asbâb al-nu₹̂ul (sebab-sebab turunnya ayat), terutama jika asbâb al-nu₹̂̂ul itu terkait dengan kisah-kisah isrâ'îliyyât yang belum dapat dipastikan otentisitas dan kebenarannya, menjelaskan keanekaragaman qirâ’ah tanpa pernah memberikan penilaian mengenai status masing-masing qirâ'ah tersebut, berhati-hati terhadap kisah-kisah isrâ'îliyyât, bersikap tawassuth (mengutamakan jalan tengah) dalam

47Al-Mâturîdî, Ta'wîlât..., 16-8 dan al-Jashshâsh, A A kkâm..., 12-6.

48Ibid., 20-2 dan al-Jashshâsh, A $\underline{b k a ̂ m . . ., ~ 18-32 . ~}$ 
menyikapi perbedaan pendapat di antara mazhab-mazhab teologi dan cenderung mengikuti mazhab Hanafî dalam melakukan istinbâth hukum.

Sebelumnya nama al-Mâturîdî tidak dicantumkan dalam deretan para ahli tafsir pada zamannya. Kemungkinan, penyebab utama yang mengakibatkan nama al-Mâturîdî terlupakan adalah dikarenakan magnus opus-nya Ta'wîlat Abl al-Sunnab tersebut tidak sampai ke tangan para penulis sesudahnya. Satu yang pasti, tulisan ini menemukan fakta baru bahwa al-Mâturîdî tidak hanya "pakar" dalam bidang teologi, namun juga "ahli" dalam bidang tafsir al-Qur'an.

\section{Daftar Pustaka}

'Alî 'Abd al-Fattâh Al-Maghribî, Imâm Abl al-Sunnab wa al-

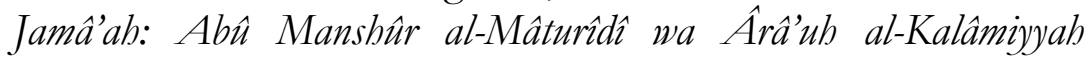
(Mesir: Maktabah Wahbah, 1985).

Abd al-Wahhâb Faydl, Manhaj Ibn 'Athiyyah fî Tafsîr al-Qur'ân al'Azîm (Kairo: Al-Hay'ah al-'Âmmah li Syu'ûn al-Mathâbi' alAmîriyyah, 1973).

Abû al-Khayr Muhammad Ayyûb 'Alî, 'Aqîdah al-Islâm wa alImâm Al-Mâturî̀î (Bangladesh: al-Muassasah al-Islâmiyyah, 1983).

Abû Bakr A $\underline{h m a d}$ al-Râzî Al-Jashshâsh, A $\underline{h} k \hat{a} m$ al-Qur'ân (Beirut: Dâr al-Fikr, 1993).

Abû Bakr bin Aḥmad bin Muhammad bin Muhammad bin Qâdî Syuhbah, Thabaqât al-Syâfi'iyyah (Beirut: 'Âlam al-Kutub, 1986).

Abû Mansyûr Al-Mâturîdî, Kitâb al-Tawhî̉d (Istambul: alMaktabah al-Islâmiyyah, 1979). Ta'wîlât Abl al-Sunnah (Baghdâd: al-Irshâd, 1983).

Ahnmad Al-Syirbâsyî, Qishshât al-Tafsîr (Kairo: Dâr al-Qalam, 1962). 
Ahmad Amîn, Zubr al-Islâm (Kairo: Lajnat al-Ta'lîf wa alTarjamah wa al-Nashr, 1952).

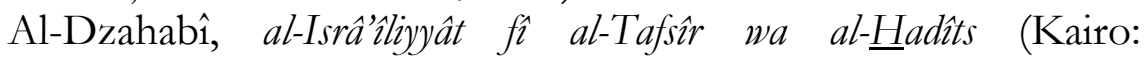
Mathba'ah al-Azhar, 1987).

Karim (Kuwait: Dâr al-I'tishâm, 1976). , Al-Tafsîr wa al-Mufasirûn (Kairo: Dâr al-Kutub al-

Hadîtsah, 1976).

G.E. Von Grunebaum, Classical Islam, ter. Katherine Watson (Chicago: Aldine Publishing Company, 1970).

Harun Nasution, Islam Ditinjau Dari Berbagai Aspeknya (Jakarta: UI Press, 1978).

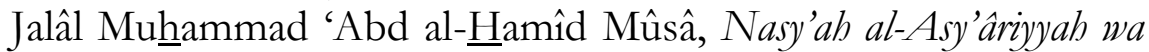
Tathawwurubâ (Beirut: Dâr al-Kutub al-Lubnânî, 1975.

Mannâ' Al-Qaththân, Mabâhits fî̀ Ulûm al-Qur'ân (Riyadl: Mansyûrât al-'Ashr al- $\underline{\text { Hadîts, }}$ 1973).

Muhammad 'Abd al-'Azîm Al-Zarqânî, Manâbil al-Irfân fì 'Ulûm al-Qur'ân (Beirut: Dâr al-Fikr, 1988).

Muhammad bin Luthfî Al-Shabbâgh, Lamabât fî̀ Ulûm al-Qur'ân wa Ittijâhât al-Tafsîr (Beirut: al-Maktab al-Islâmî, 1990).

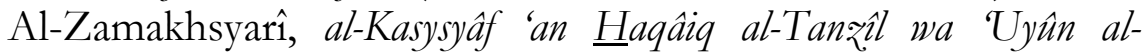
Aqâwîl fì Wujûh al-Ta'wîl (Beirut: Dâr al-Fikr, t.t).

Al-Zarkasyî, Al-Burbân fì Ulùm al-Qur'ân (Beirut: Dâr al-Kutub al-'Ilmiyyah, 1988). 